\title{
Policy Responses to Direct and Underlying Drivers of Deforestation: Examining Rubber and Coffee in the Central Highlands of Vietnam
}

\author{
Gabrielle Kissinger ${ }^{1,2}$ \\ 1 Lexeme Consulting, Vancouver, BC V6Z 1C2, Canada; gabrielle@lexemeconsulting.com \\ 2 Environmental Policy Group, Wageningen University \& Research, 6706 Wageningen, The Netherlands
}

Received: 12 May 2020; Accepted: 30 June 2020; Published: 6 July 2020

\begin{abstract}
Viet Nam's Central Highlands are a priority region for its National REDD+ Action Plan (NRAP) to reduce emissions from deforestation and forest degradation but are under strong pressures from rubber and coffee production and expansion into forests, and future climate stress. This research explores to what extent REDD+ and sectoral policy interventions have addressed both the direct and underlying drivers of deforestation and forest degradation in this region, with particular focus on the actors and scales that policy interventions must reach to affect driver pressure. National-level policy responses to driver pressures are assessed, with the results indicating poor correlations between the direct drivers and related underlying drivers. The research proposes a framework to guide the policy design and evaluation of response options to enable identification of the causal connections between direct and underlying drivers, and consider future pressures, which actors to target (or not miss) and which scales are best suited for interventions (from international to national, sub-national and local). This is highly relevant for countries pursuing forest and land use sector solutions through Nationally Determined Contributions to the Paris Agreement and REDD+.
\end{abstract}

Keywords: policy; direct and underlying drivers of deforestation; coffee; rubber; central highlands; Viet Nam

\section{Introduction}

Viet Nam was an early adopter of REDD+ (REDD+: Reducing emissions from deforestation and forest degradation and the role of conservation, sustainable management of forest and enhancement of forest carbon stocks.), joining the UN-REDD Programme in 2009, and its World Bank Forest Carbon Partnership Facility project was approved in 2013. While Vietnam has successfully increased its forest cover since 1990, with natural forest, forest/tree plantations and rubber plantations expanding from 9.4 million ha in 1990 to 14.8 million ha nationally by 2015 [1], the quality of the forest has declined, and mature natural forests decreased 13.5\% between 1995 and 2010 [2]. Particularly in the Central Highlands of Viet Nam, which is a priority region for the National REDD+ Action Plan (NRAP), natural forest area has decreased, while agricultural production has increased for coffee, rubber, pepper, cassava and other products that compete for expansion into forested areas [3].

Based on Viet Nam's NRAP and other policy implementation efforts, this paper explores to what extent policy interventions are addressing the direct and underlying drivers of deforestation and forest degradation in the Central Highlands of Viet Nam. The emphasis of this research is on the underlying drivers, specifically in the rubber and coffee sectors, which Viet Nam has identified as the two largest drivers within the timeframe assessed in Viet Nam's NRAP [3]. Based on the assessment of underlying drivers in these two commodity sectors in the Central Highlands, this research then explores the actors and scales that have been prioritized in policy interventions. That provides a basis for also 
exploring missing policy interventions, actors and scales, and what factors may have contributed to that. The objective is to test the utility of the drivers of land use change, interventions, actors and the scales framework (Figure 1) below. This paper does not attempt to evaluate the effectiveness of these interventions to date to measurably impact driver pressures, though that could be an area of future research when Viet Nam is farther along in NRAP implementation.

The insights from this research may be relevant to other countries seeking to implement REDD+, and those with land use sector mitigation pledges to the Paris Climate Agreement. Developed and developing countries agreed to the Cancún Agreement at the United Nations Framework Convention on Climate Change (UNFCCC) COP in 2010 and the Warsaw Framework at UNFCCC COP 19 in 2013, which stated that a phased approach for REDD+ was required, and called for countries to first assess drivers, then develop national strategies and action plans to identify and then implement policies and measures to address pressures from drivers of deforestation and forest degradation [4,5]. Decision 15 of the Warsaw Framework reflected the need for the scope of action by countries to also include organizations and the private sector to contribute in taking action to reduce direct and underlying drivers [5]. International sources of support to developing countries for REDD+ have emphasized the need to focus on the assessment of direct and underlying drivers and develop policy interventions in response to those [6-8]. UN agencies and the World Bank have, to date, supported 64 and 47 developing countries, respectively, across Africa, Asia-Pacific, and Latin America and the Caribbean to promote climate, forest and development goals [7,8]. More than 60 countries have included avoided deforestation (and 100 included agriculture actions) in their Nationally Determined Contributions to the Paris Climate Agreement [6]. While these programmes assist countries in achieving joint commitments and funding under the UNFCCC, it is up to countries to determine how to respond to driver pressures in their forest and land use sectors, based on national circumstances. However, country progress, and political willingness, to tackle the drivers in REDD+ readiness was found to be slow and inadequately defined in policy and strategy development and implementation across 47 countries reviewed [9].

There is a lack of clear causal links between direct and underlying drivers in the REDD+ literature, thus this study seeks to provide evidence of this link and the role it plays in designing policy solutions to drivers. While there is a growing body of literature on the causes of deforestation and forest degradation, there has been less assessment in the literature of what enables effective policies to address drivers and influence transformational change in the REDD+ policy domain. A Center for International Forestry Research (CIFOR) Global Comparative Study on REDD+ provides insights into the role of institutional settings and policy arenas at national levels affecting the direction of REDD+ policies and their implementation [10]. Another meta-analysis across a range of counties affirms that policies that can successfully insulate the forest frontier from the influence of high-commodity prices have great potential to reduce deforestation [11]. Forms of hybrid public-private interventions on land use are expanding, and aligning private and public regulations of land use is found to influence effectiveness [12]. However, despite corporate commitments and government efforts to stem deforestation, the rate of agricultural, commodity-driven deforestation has not declined [13]. Though forest area is decreasing globally, and the rate of loss has slowed between 2015 and 2020 compared to the 1990s and early 2000s [14], agricultural expansion continues to be the main driver of deforestation and forest fragmentation [14]. This research contends that the lack of connection between direct and underlying drivers largely explains why deforestation rates have not declined, despite policy efforts.

The analytical framework used to assess the data and information gathered in Viet Nam and the Central Highlands and an overview of the methodology applied in the inquiry is presented below (Section 2). Section 3 provides an overview of the direct and underlying drivers of deforestation in the Central Highlands of Vietnam. Section 4 details the results of the analysis of Viet Nam's policy responses to direct and underlying driver pressures from agricultural commodities in this context, followed by a discussion of what conclusions can be drawn from the assessment, and what implications these have for policy-makers. 


\section{Analytical Framework and Methods}

Direct drivers of deforestation or forest degradation are human activities or immediate actions that directly impact forests and land [15], such as logging, agricultural expansion, or infrastructure and road development. These are visible to the eye, but the underlying causes that motivated them are harder to detect and quantify. Working behind the direct drivers of forest loss or degradation are the underlying drivers, which must be addressed in any effort to reduce pressures on forests $[15,16]$. Underlying causes are complex interactions of fundamental social, economic, political, cultural and technological processes that are often distant from their area of impact. Interactions and feedbacks occur between the direct and underlying drivers, which are often complex, and the mechanisms that convey them may be hard to decipher. Here, we use the term 'drivers' to refer to both direct and underlying drivers.

\section{INTERVENTIONS CHANGE DRIVERS}

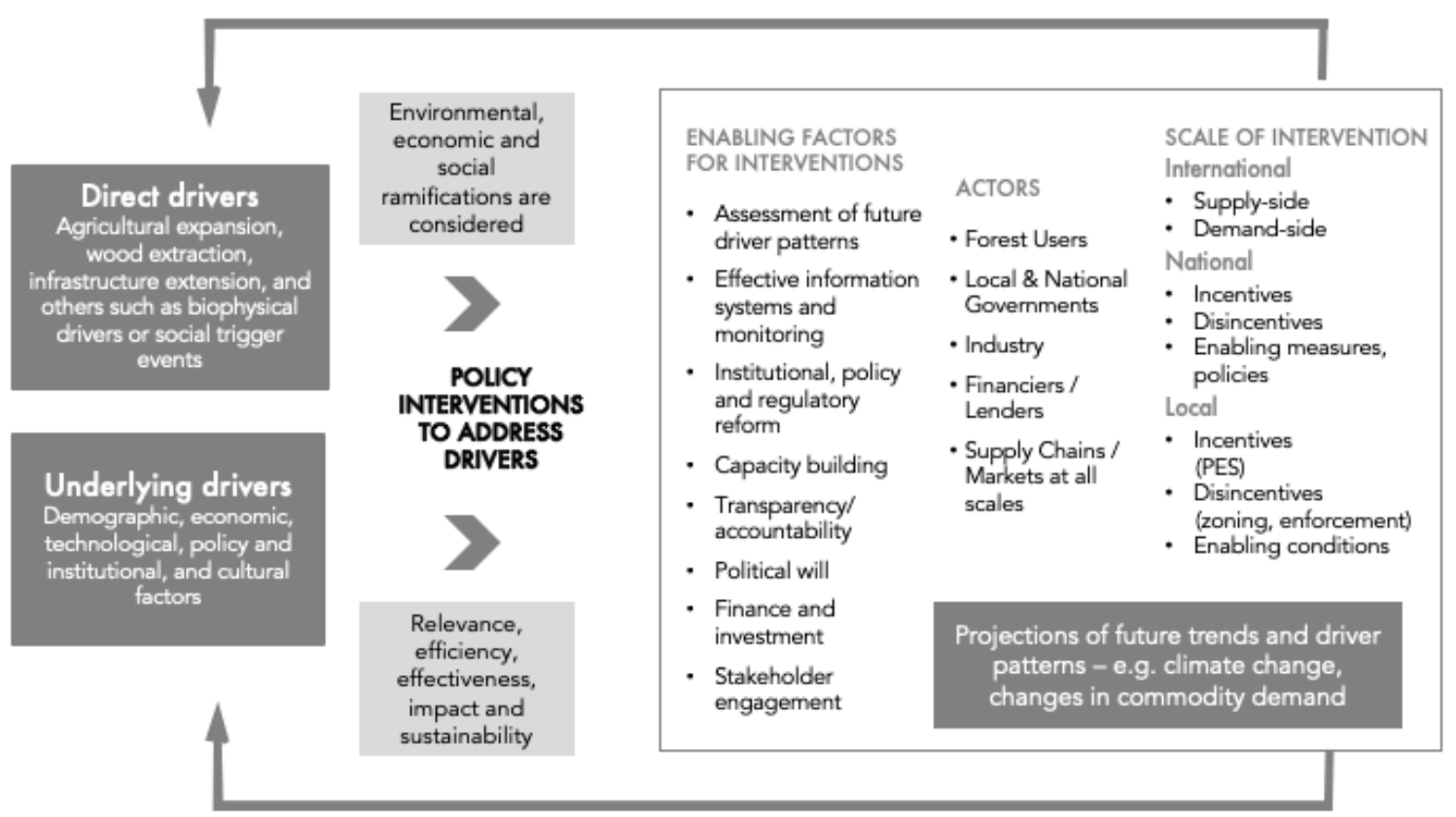

INTERVENTIONS CHANGE DRIVERS

Figure 1. Drivers of land use change, interventions, actors and scales framework. Source: Adapted from Kissinger et al (2012) [16].

This paper expands upon the drivers of deforestation and forest degradation framework developed by Geist and Lambin [15] and refined in Kissinger et al. [16], which added policy response and intervention aspects to addressing drivers of deforestation and forest degradation. This added the policy process aspects that must be implemented to affect driver pressure-that incentives, disincentives and enabling measures will need to reach the actors responsible for addressing the drivers of deforestation and at the appropriate scale (international, national and local). Enabling factors such as effective information systems to guide decisions, institutional capacity, transparency and accountability, political will and consultation with stakeholders underpins strategies to affect drivers. Kissinger et al. [16] also identified that many drivers will require interventions at multiple scales, ranging from international (e.g., in relation to international commodity demand), national (e.g., national laws and incentives), and local (e.g., local zoning, enforcement). The policy response component of the framework is viewed from the vantage point of national-level governments and policy-makers, who are in a position to balance both the public and private values in the response (and hence most able to consider the economic, environmental and social aspects). 
This research pursued analyzing how the elements in drivers of land use change, interventions, actors and scales framework (the framework) played out in Viet Nam's NRAP and related responses to driver pressures in the Central Highlands. The research relied on a mixed methodology approach consisting of qualitative analyses of policy documents, and primary data gathered through interviews with 130 individuals from 78 organizations and departments (see Table 1). Interviews were held in May 2018 with relevant government officials at central, provincial and district levels; agriculture sector actors (ranging from international agribusinesses sourcing in Vietnam to traders and smallholder producers); research organizations, and farmer organizations. Interviewees were determined based on consultations with multi-lateral development partners, CSO input, and open calls for participation by MARD staff at Central and Provincial government levels, and DARD staff at district levels. Additional interviews occurred in October 2018. Interviews occurred in Hanoi, Ho Chi Minh City, Da Lat in Lam Dong Province, Gia Nghia in Dak Nong Province, and two districts in each of the provinces. The secondary data assessed were based on remote sensing information developed by the Government of Vietnam. The Viet Nam rubber and coffee case studies were based on both secondary and primary data, starting with a comprehensive literature review on drivers in the Central Highlands, and then on each of the two commodities. Policy documents were coded according to the core elements of the conceptual framework above, with added emphasis on capturing all relevant information related to policy responses to the underlying drivers. Vietnamese documents were translated with Google translate, and verified by native Vietnamese speakers.

Table 1. Summary of interviews.

\begin{tabular}{|c|c|c|}
\hline Organization Type & Individuals & Organizations \\
\hline \multicolumn{3}{|l|}{ National government } \\
\hline Ministry of Agriculture and Rural Development staff & 8 & 3 \\
\hline Other govt ministries & 8 & 5 \\
\hline \multicolumn{3}{|l|}{ Provincial government } \\
\hline Lam Dong & 15 & 8 \\
\hline Dak Nong & 8 & 4 \\
\hline \multicolumn{3}{|l|}{ District government } \\
\hline Lam Dong_Lac Duong district & 11 & 5 \\
\hline Lam Dong-Di Linh District & 3 & 3 \\
\hline Dak Nong-Dak Song district & 6 & 4 \\
\hline Dak Nong-Dak R'Lap district & 7 & 6 \\
\hline Dak Nong-Dak Glong district & 7 & 6 \\
\hline Banks and lenders & 7 & 3 \\
\hline \multicolumn{3}{|l|}{ Industry } \\
\hline Rubber-public sector & 1 & 1 \\
\hline Coffee-private sector & 8 & 6 \\
\hline Smallholder producers-cooperatives & 5 & 3 \\
\hline Smallholder producers-farm-level assoc. & 5 & 5 \\
\hline Forest companies & 3 & 2 \\
\hline Forest cooperatives & 4 & 2 \\
\hline CSO & 3 & 2 \\
\hline \multicolumn{3}{|l|}{ Research } \\
\hline CGIAR center representatives in Viet Nam & 7 & 3 \\
\hline $\begin{array}{c}\text { Donors, multi-lateral and bi-lateral assistance agencies, } \\
\text { development assistance organizations }\end{array}$ & 14 & 7 \\
\hline Total: & 130 & 78 \\
\hline
\end{tabular}

Source: Author generated.

In assessing the information according to each element of the framework, the following questions were posed: (a) to what degree were direct drivers identified; (b) to what degree were underlying drivers identified; (c) were interlinkages between the direct and underlying drivers made clear; (d) did policy interventions reach key actors responsible for driver activity; (e) did policy interventions touch 
actors at the scales they operate at? Thus, the assessment sought to identify how policymakers attune their policy responses to direct and underlying drivers, which actors are reached with interventions, and at what scale those interventions occur at.

\section{Direct and Underlying Drivers in the Central Highlands of Viet Nam}

This section begins with an overview of the direct and underlying drivers of deforestation and forest degradation that Viet Nam identified in preparation for the NRAP, and other sources, with an emphasis on those that are relevant for the Central Highlands region (including the Provinces of Kon Tum, Gia Lai, Lam Dong, Dak Lak, and Dak Nong). This section then summarizes the key policy interventions that Viet Nam has taken to advance its forest sector emission reduction goals, and policy interventions that occurred in the driver sectors of rubber and coffee.

Viet Nam defines forest (Source: Circular No. 34/2009/TT-BNNPTNT) as an area with perennial timber trees, bamboos and palms of all kinds of a minimum height of $5 \mathrm{~m}$, minimum tree cover of $10 \%$, and a minimum plot area of 0.5 hectares or forest tree strips of at least $20 \mathrm{~m}$ in width and of at least three tree lines [2]. Rubber trees count as forest if they meet the aforementioned definition of an area [2]. Forest cover change and forest loss in the Central Highlands was considerable during the Viet Nam War. Forest cover nationally declined to an estimated $28 \%$ by 1993 , compared to $43 \%$ in 1943 [17]. After the mid-1990s, forest cover increased. Meyfroidt and Lambin [18] found that nationally, reforestation during the 1990s and 2000s occurred at a higher rate than deforestation, due to a rapid increase in plantations and regrowth of some natural forests. Natural forest, forest and tree plantations and rubber plantations expanded from 9.4 million ha in 1990 to 14.8 million ha nationally by 2015 [1]. However, the quality of the forest has decreased, and by 2010, two-thirds of Vietnam's natural forests were considered poor or regenerating, and rich and closed-canopy forest constituted only $5 \%$ of the total by 2010 [2]. There was a decline in cultivation on hillsides (attributed to shifting cultivation), followed by reforestation [18]. Population growth and land scarcity drove an intensification of agriculture, mainly based on increased labour inputs on the most suitable plots and abandonment of marginal lands to reforest [19]. Other causes were new policies that allocated forest land to households, scarcity of forest products for local markets that spurred planting, and increased urban and industrial demand for timber [19]. However, the Deltas and the Central Highlands regions were less affected by these patterns, and continued to show high levels of deforestation [20]. Between 2000-2010, the Central Highlands had the third largest area of deforestation and forest degradation compared with other region, with $8.4 \%$ of the total natural area [21]. Between 2005-2015, the loss of natural forests was 582,657 ha $(32 \%$ reduction in area) [22,23], and in the same period, 2.4 million ha of forests in the Central Highlands were degraded [2].

The largest driver of deforestation, and thus conversion of forest to other uses between the years 2005-2015 was commercial agriculture. Table 2 summarizes the primary direct drivers and corresponding underlying drivers, as per studies which informed development of the National REDD+ Action Plan. The largest direct driver was rubber, closely followed by coffee. Between 2005 and 2015 , rubber area increased by over 172,308 ha (a 198\% increase), coffee area increased by 106,000 ha (a $29 \%$ increase), cassava area reached 157,292 ha and pepper planting area increased by 52,000 ha (106\% increase) [23]. Coffee expansion was highest between 1990 and 2000, when 500,000 ha was converted across the Central Highlands [24,25], and in the five year period between 1995 and 2000, Lam Dong Province saw coffee area increase by 77\% [26]. Cassava is a crop that quickly depletes soil nutrients [27] and is a transition crop. The establishment of forest plantations also drove conversion of forests for the international woodchip market after 1995 [23], but this has slowed, and more recent policies favour native tree species and long-term rotation plantations for saw-log production [3]. 
Table 2. Direct and underlying drivers of deforestation in the Central Highlands of Viet Nam.

\begin{tabular}{|c|c|c|c|}
\hline Driver & Direct Driver Impacts & Related Underlying Drivers & Cross-Cutting Underlying Drivers \\
\hline Direct-Rubber expansion & $\begin{array}{l}\text { Between } 2005 \text { and } 2015 \text {, increased } \\
198 \%(<172,308 \text { ha })\end{array}$ & $\begin{array}{l}\text { - } \quad \text { High commodity prices up to 2011; } \\
\text { Lack of ability by Central government to } \\
\text { limit rubber area (land allocation decisions } \\
\text { occur at district levels and Provincial } \\
\text { planning); } \\
\text { - } \quad \text { Legal loopholes allowed for conversion of } \\
\text { natural forest to rubber; } \\
\text { - Low operational standards; }\end{array}$ & \multirow{4}{*}{$\begin{array}{l}\text { - } \quad \text { Perceived abundance of land resources; } \\
\text { - } \quad \text { High poverty rates; } \\
\text { - } \quad \text { tenure rights; } \\
\text { - } \quad \text { Poor agronomic practices; } \\
\text { - } \quad \text { Disconnect between national priorities and } \\
\quad \text { Provincial implementation. }\end{array}$} \\
\hline Direct-Coffee expansion & $\begin{array}{l}\text { Between } 2005 \text { and 2015, increased } \\
29 \%(106,000 \text { ha) }\end{array}$ & $\begin{array}{l}\text { - High commodity prices, especially in the } \\
\text { mid- to late-1990s; } \\
\text { Mass migrations, supported by government } \\
\text { policies and institutions; } \\
\text { Utilization of annual crops (mainly cassava) } \\
\text { as a stepping-stone toward tree-crop } \\
\text { establishment (in freshly cleared forest); } \\
\text { - Lack of smallholder access to finance; }\end{array}$ & \\
\hline Direct-Cassava expansion & Reached 157,292 ha by 2015 & $\begin{array}{l}\text { Annual crop, easy to grow on freshly cleared } \\
\text { land as transition plant before establishing } \\
\text { tree crops (such as coffee); } \\
\text { - Difficult to regulate; }\end{array}$ & \\
\hline Direct-Pepper expansion & $\begin{array}{l}\text { Between } 2005 \text { and } 2015 \text {, increased } \\
106 \%(52,000 \text { ha })\end{array}$ & - High commodity prices. & \\
\hline
\end{tabular}


The general cross-cutting underlying drivers identified in Viet Nam's updated 2017 NRAP are: (a) high poverty rates in the forest dwelling communities, and a lack of access to land and forests, especially in the Central Highlands where much of the forest remains under the management of State Forest Management Units and Commune Peoples Committees; (b) prioritisation of economic growth over forest protection, resulting in forest being lost legally (such as planned loss due to hydropower development), and illegally (such as illegal expansion of agriculture into forested areas); (c) current agronomic practices are generally of poor quality, and therefore yield increases often come at the expense of forests; (d) inadequate implementation of national policies to promote sustainable development at the provincial level remains an underlying cause, particularly in the more remote regions [3].

More specific underlying drivers are associated with each of the commodities, with unique causal linkages forming between underlying drivers and direct drivers over time.

\subsection{Rubber}

For rubber, the high prices for natural rubber up to 2011, lack of ability by the central government to limit rubber area (land allocation decisions occur at district levels and Provincial planning), and loopholes which allowed for the conversion of natural forest to rubber are notable. The impact of the commodity prices clearly had a large effect driving rubber expansion. When rubber prices were high (USD 6.26/kg on world markets in February of 2011), the area of crop production in Dak Nong Province between 2008 and 2011 increased over 400\%. Only after record low prices of USD 1.23/kg in early 2016 did planted area significantly contract, and this also illustrates the delay in response to the downturn in price signals [30]. The current prices are around USD 1.5/kg [31]. Though overall production remains strong, the return on the investment is very low.

Another key underlying driver was the lack of ability of the central government to limit rubber area, lack of coordination and enforcement at Provincial levels, and gaps in policies regarding forest conversion for plantations that weakened enforcement processes. Though the Central government sought to limit expansion, rubber area is expected to reach 343,893 ha in the Central Highlands by 2020, far exceeding the 280,000 ha target identified in the 2009 Rubber Development Strategy (Decision No. 750/QD-TTg of the Prime Minister, of June 2009, on rubber development to 2015 and vision to 2020) [32]. In many areas, it was also found the areas planted fell far short of the goals identified in the original investment certificates, indicating that some actors cleared land and sold the trees (e.g., conversion timber), but never followed through on establishing plantations [30,33]. By 2012, $79 \%$ of the rubber plantation areas in the Central Highlands were converted from natural forest and were not necessarily classified as degraded forest, which would have been the suitable forest type to covert to other uses under Vietnamese law [34]. This indicates legal loopholes which allowed for the conversion of natural forest to rubber. The criteria to classify poor forest was based on volume of trees (with diameter $>8 \mathrm{~cm}$ ) being less than $100 \mathrm{~m}^{3} / \mathrm{ha}$, which resulted in other attributes such as biodiversity or protection functions not being part of the selection criteria. Decisions on converting natural forest on less than 200 ha are authorized as a provincial level decision, rather than requiring a central level approval. This results in mistakes in implementation at the local level, without central level input or monitoring [34]. These aspects, combined with high expectations based on rubber prices, have resulted in rapid expansion.

Poor governance of the sector's production standards and practices is an underlying driver, and this extended into neighboring countries, notably when Viet Nam Rubber Group's Forest Stewardship Council (FSC) certification was revoked in 2015 [35].

\subsection{Coffee}

The causal linkages between direct drivers and underlying drivers are nuanced across the Central Highlands, and varied over time. Overall, a range of underlying drivers influenced coffee expansion, including mass migrations, supported by government policies and institutions, surging 
coffee commodity prices (especially in the mid- to late-1990s), lack of tenure rights for ethnic and poorer farmers, utilization of annual crops (mainly cassava) as a stepping-stone toward tree-crop establishment (in freshly cleared forest), lack of smallholder access to finance and dependence on supply chain finance with high interest rates.

Though government policy support, planning and subsidies initiated the industry through collective farming systems during the late 1970s and early 1980s, the government enabled farmers (at household levels) to expand the industry through the Đổi Mới market liberalization and land reforms during the late 1980s and 1990s. Viet Nam is now the world's second largest exporter of coffee (behind Brazil) and the biggest Coffea canephora (Robusta) coffee producer. The sector provides a livelihood for around 2.6 million people- 600,000 of whom are smallholder family farmers on one hectare or less, sometimes dispersed among several plots [36].

In-migration to the Central Highlands is a complex underlying driver, with added side effects related to poverty, land rights, landlessness, and perceived conflicts between indigenous ethnic people, ethnic migrants, and the Kinh national ethnic majority. The population of the Central Highlands almost doubled between 1991 and 2014 [37]. The migration and development of industrial crops in the Central Highlands is one of the main reasons that traditional patterns of ethnic people living with the forest has shifted [38], displacing ethnic people deeper into forest frontiers. This pattern is particularly evident in Dak Nong Province [33-40]. The de-collectivization process of the Đổi Mới market liberalization and land reforms weakened indigenous people's communal land tenure and stewardship practices, and the land reforms favoured permanent agricultural land [37]. Thus, many poorer and ethnic households do not have "Red Book" land title certificates, which is standard collateral for loans and financing [40]. Ethnic minority farmers are found to have less liquidity than Kinh ethnic majority farmers, and thus are less able to ride out changes in commodity prices and more likely to switch to other crops [41,42]. The lack of access to finance for poor and ethnic people restricts their ability to invest in both annual and perennial crops that require high upfront investments, such as coffee and rubber, which pushes them towards transitional crops such as cassava.

Cassava cultivation has been a driver of forest loss, and enabler of longer-term perennial crops such as coffee [43]. Deforestation was mainly caused by the acquisition and conversion of agricultural lands to perennial crops by capital-endowed households, often from the Kinh ethnic majority, and corresponding displacement of poor households of ethnic minorities, relying on shifting cultivation towards the forest margins [43]. Cassava is lucrative, with the export volume of cassava products in 2017 roughly USD 1.03 billion [44], the majority of which goes to China. Most of the current cassava area is believed to be cultivated on forestry land or former forestland. Cassava expansion traces a unique pattern, as small and undetectable incursions into forest occurs, to occupy land for the future purpose of creating a new source of land for other commodity crops such as rubber, coffee, pepper or dragon fruit. After a few years of cassava cultivation, these areas are often transferred to other owners and uses [45]. This disrupts societal patterns, creating a change in the concept of land value, and the right to access, use and benefit from forest and forest land in some areas, especially for ethnic minorities [45]. Cassava is thus directly related to coffee expansion, but is harder to regulate and manage than other crop types, and is of growing economic importance to ethnic minorities living in the forest frontier.

While it is important to chart the historical trajectory of drivers and underlying causes, there are indications that the contemporary and future patterns are different. During the past 2-3 years, more farmers were switching from producing coffee to growing other cash crops such as black pepper, avocado, and passion fruit to generate higher incomes. This is due to the low coffee commodity prices, and current rates of high production could suppress the coffee price to a point where farmers would no longer find it financially feasible to grow coffee [46]. This change is reducing coffee areas, especially in Dak Lak, where arable land is limited. In other provinces like Dak Nong and Lam Dong, where arable land reserve is still available, the new arable land is used more for growing black pepper and avocado [47]. 


\section{Policy Review and Discussion}

This section analyzes Viet Nam's policy responses to REDD+ and rubber and coffee drivers, in relation to advancing its National REDD+ Plan (2012 and 2017 versions) and sector responses to rubber and coffee expansion. Interviews helped inform decisions on which policies to include in the analysis, given the abundance of policy directives in Viet Nam. Policies and directives were assessed according to whether they include interventions targeted at direct drivers, underlying drivers, if they have no specific provisions related to drivers, and if the policy objectives are in conflict with REDD+ objectives. The analysis seeks to decipher the degree to which policy interventions sought to address not only direct drivers, but also the related underlying drivers, and to draw out how these causal connections were addressed in policy responses (as per Figure 1). The findings are summarized in Table 3, and further detail on each policy is contained in Appendix A. This section includes an analysis of how the policy interventions considered key actors and scales, focussing on those that were missed in the policy processes, yet have a clear role in driver activity (either positive or negative). Future driver pressures are also considered (as per Figure 1), as these have implications for policy responses. The discussion of the implications of these findings is contained throughout the section.

Table 3. The degree to which policies and laws related to National REDD+ Action Plan (NRAP) implementation include interventions aimed at direct and underlying drivers.

\begin{tabular}{|c|c|c|}
\hline Policy & $\begin{array}{l}\text { Interventions Directed } \\
\text { at Coffee and Rubber } \\
\text { Direct Drivers }\end{array}$ & $\begin{array}{l}\text { Interventions Directed } \\
\text { at Related Underlying } \\
\text { Drivers }\end{array}$ \\
\hline \multicolumn{3}{|l|}{ General and forest sector } \\
\hline \multicolumn{3}{|l|}{$\begin{array}{l}\text { Law on Forestry-No. 16/2017/QH14 (2017, effective } \\
\text { January 2019) }\end{array}$} \\
\hline \multicolumn{3}{|l|}{$\begin{array}{l}\text { FLEGT VPA - Viet Nam and European Union (2018, } \\
\text { effective June 2019) }\end{array}$} \\
\hline \multicolumn{3}{|l|}{$\begin{array}{l}\text { Incentive policies for enterprises investing in } \\
\text { agriculture and rural areas-Decree No. } \\
\text { 57/2018/ND-CP (17 April 2018) }\end{array}$} \\
\hline \multicolumn{3}{|l|}{$\begin{array}{l}\text { Planning Law-Law No. 21/2017/QH14 (2017, } \\
\text { effective } 1 \text { January 2019) }\end{array}$} \\
\hline \multicolumn{3}{|l|}{$\begin{array}{l}\text { Criminal code-Law No. 100/2015/QH13 (June 2017, } \\
\text { effective } 1 \text { January 2018) }\end{array}$} \\
\hline \multicolumn{3}{|l|}{$\begin{array}{l}\text { Decision No.: 886/QD-TTg,-Target Program for } \\
\text { Sustainable Forest Development for the 2016-2020 } \\
\text { Period (2107) }\end{array}$} \\
\hline \multicolumn{3}{|l|}{$\begin{array}{l}\text { Decision No. 419/QD-TTg of Prime Minister-2017 } \\
\text { National REDD+ Action Programme) (5 April 2017) }\end{array}$} \\
\hline \multicolumn{3}{|l|}{$\begin{array}{l}\text { Directive 13-CT/TW -Enhancing Party's leadership } \\
\text { in forest management, protection and development } \\
\text { (12 January 2017) }\end{array}$} \\
\hline \multicolumn{3}{|l|}{$\begin{array}{l}\text { Prime Minister's Notice No. } \\
\text { 191/TB-VPCP-Conclusion of the Prime Minister at } \\
\text { the Conference on Sustainable Forest Restoration } \\
\text { Solutions in the Central Highlands (2016-2020) (22 } \\
\text { July 2016) }\end{array}$} \\
\hline \multicolumn{3}{|l|}{$\begin{array}{l}\text { Law on Crop Production -Law No. 31/2018/QH14 } \\
\text { (2018) }\end{array}$} \\
\hline \multicolumn{3}{|l|}{$\begin{array}{l}\text { Viet Nam's Nationally Determined Contribution to } \\
\text { Paris Climate Agreement (NDC) (submitted to } \\
\text { UNFCCC in October 2015) }\end{array}$} \\
\hline $\begin{array}{l}2012 \text { National REDD+ Action Programme-Prime } \\
\text { Minister's Decision No. 799/QD-TTg (27 June 2012) }\end{array}$ & & \\
\hline
\end{tabular}


Table 3. Cont.

\begin{tabular}{lll}
\hline Policy & $\begin{array}{l}\text { Interventions Directed } \\
\text { at Coffee and Rubber } \\
\text { Direct Drivers }\end{array}$ & $\begin{array}{l}\text { Interventions Directed } \\
\text { at Related Underlying } \\
\text { Drivers }\end{array}$ \\
\hline Sector-specific: Rubber & \\
\hline $\begin{array}{l}\text { Decision of the Prime Minister 899/QD-TTg, 2013 } \\
\text {-Agricultural restructuring towards raising added } \\
\text { values and sustainable development }\end{array}$ & \\
\hline Directive No. 1685 / CT-TTg of 2011 & \\
\hline Sector-specific: Coffee & \\
\hline Sustainable Coffee Plan to 2020 and Vision to 2030 \\
(2016)
\end{tabular}

Key:

Interventions clearly target drivers and are legally enforceable Interventions loosely target drivers and may or may not be legally binding Interventions do not target drivers

Interventions are at cross-purposes to REDD+ objectives

\subsection{Policies that Include Interventions Targeted at Direct Drivers}

Under the category of general laws/policies and forest sector-specific ones, Viet Nam's 2012 NRAP stands out as lacking policy objectives to address drivers outside the forestry sector. Recognizing this, the 2017 NRAP (Decision No. 419/QD-TTg of Prime Minister) included the principle that "the REDD+ activities address, inter alia, the drivers of deforestation and forest degradation, (and) forest governance issues [48]." In defining this broader scope, the NRAP included the following policies and measures directed at both direct and underlying drivers: (a) review and adjust the land use masterplan and land use plans to ensure that the target of 16.24 million hectares of forest land is achieved by 2020, (b) promote sustainable and deforestation-free agriculture and aquaculture; (c) improve forest governance and livelihoods for people living near and in the forest; (d) strengthen law enforcement [48]

Although the 2017 NRAP intended to promote sustainable and deforestation-free agriculture, this intention must find its way into the matrix of already existing and emerging policies and programmes. This inherently results in the fragmentation of intervention actions and instruments, which are difficult to coordinate programmatically and temporally. A Crop Production Law, new Planning Law, and Forest Law were passed by the National Assembly in 2017-2018, but none of these contain specific provisions that reference the NRAP goals and specify implementation modalities. Although a new Law on Forestry was passed in 2017, most policies and measures that would be necessary to affect rubber, coffee and any other drivers outside the forest sector would occur through other laws, with the exception of provisions related to the conversion and repurposing of forest land. Understandably, it may be challenging to include interventions aimed at rubber and coffee in the Forest Law, but these presumably could have been included in the Crop Production Law. This issue raises the challenge of influencing priorities in other sectors.

Notably, the Prime Minister's Notice 191 of 2016 placed a moratorium on any new clearing of natural forest, freezing the remaining 2.25 million ha of natural forest. It is identified by those interviewed as having the most impact on direct drivers from rubber and coffee pressure in the Central Highlands. This simply worded policy commitment signaled that no more rubber and coffee expansion is allowable. Notice 191 has been integrated into land allocation decisions at district and provincial levels, and even into lending decisions by banks, such as the Viet Nam Bank for Social Policies (VBSP) which lends to smallholders, Viet Nam Bank for Agriculture and Rural Development (VBARD) which 
is the primary agriculture sector lender, and the Bank for Investment and Development of Viet Nam (BIDV). Loan officers at the commune or district level screen applicants for bank loans for deforestation risks. If evidence of deforestation is found, loans will not be extended, and previous loans will be recalled. This form of monitoring appears to be highly effective. However, there are also weaknesses in the policy design and implementation of Notice No. 191, as land users who are at most risk of making incursions into forests (e.g., cassava growers) largely do not access formal financing mechanisms, thus are outside the scope of bank screening.

Directive 13 of the Communist Party is viewed by some interviewees within the government as a strong policy directive on direct drivers, as it requested the Party to control socioeconomic development planning and projects which negatively affect forest area and quality, particularly in natural forest and protection forests. However, other interviewees were unaware of this Directive.

The other major policy interventions sought to direct provincial and district planners to limit areas allocated to key commodities. While these were aimed at the direct drivers of rubber and coffee expansion, the underlying drivers were not identified (such as high commodity prices, strong market demand, unclear tenure rights, etc.), and strategies developed to address these. When the Government of Viet Nam Directive No. 1685 of 2011 directed Provinces to review and evaluate projects converting forest to rubber plantations, and district Departments of Agriculture and Rural Development (DARD) adjusted rubber plantation development plans, Provincial and district offices documented the scale of the overshoot $[30,33]$. However, district DARDs were not given clear direction on how to respond to that besides adjusting spatial plans and cracking down on illegal logging and clearing (which has had mixed success, thus the 2018 FLEGT VPA establishing a Timber Legality Assurance System).

Interventions identified as loosely targeting drivers in Table 3 include those that set broad goals that could be interpreted by decision-makers in driver sectors as guidance, but interviews suggest that they were not taken on board by these sectors. These include Decision No. 886 of 2017, a Target Programme for Sustainable Forest Development, which sets goals (such as national forest cover at $42 \%$, and forest area of 14.4 million ha), and indicates domestic investment for forest protection, including for control the conversion of forest land to other purposes [49]. However, interviews suggest that it is viewed as a programme and source of financing, not a law or legal directive.

As the coffee sector in the Central Highlands was not a focus for REDD+ efforts until more recently, particularly since the 2017 NRAP, it is presumed that REDD+ goals would have been tangential in the development of the Sustainable Coffee Plan to 2020 and Vision to 2030. The Sustainable Coffee Plan does seek to limit coffee-planting area (stabilize coffee area at 600,000 ha), but seeks increased trade and export values [50]. Similarly, the Ministry of Agriculture and Rural Development and World Bank designed the Viet Nam Sustainable Agriculture Transformation (VNSat) programme, investing USD 98.7 million in the coffee sector between 2015 and 2020, for improved farm agronomic practices on 69,000 ha and the rejuvenation of aging coffee trees [51]. Though it is the largest investment in the sector in this period, it does not incorporate the drivers of deforestation and land degradation to address future climate impacts, or to remediate soils after years of nutrient depletion and fertilizer use, and related livelihood/poverty issues in coffee production.

There has been reliance on voluntary certification in the coffee sector as a preferred option to achieve sustainability (such as via the Sustainable Coffee Plan to 2020 and Vision to 2030), however demand for certified coffee from the Central Highlands has decreased. This is due to the Robusta-oriented coffee marketplace valuing low prices over quality, which means that trading is on very thin margins and there is decreased interest in paying price premiums for certified products. Further, interviews suggest that certification standards were not seen by major buyers to address the pressing sustainability issues that are beyond the farm-unit (especially water scarcity and agrochemical use).

The rubber industry committed to not expanding their area to avoid oversupply in response to the Decision of the Prime Minister 899/QD-TTg, 2013, although this was based on supply and price stabilization, not deforestation-free commitments. 


\subsection{Policies with Interventions Directed at Underlying Drivers}

Again, one of the major underlying drivers affecting both rubber and coffee expansion was the lack of ability of the central government to limit commodity areas which are related to the high market prices for commodities, and gaps in policies regarding forest conversion for plantations. The 2017 NRAP does not directly identify a policy direction on addressing underlying drivers, with the exception of two policies and measures to improve forest governance and livelihoods for people living near and in the forest, and to strengthen law enforcement [48]. Although these are not defined as being in relation to the direct drivers, a logical connection could be made in the implementation stage, in relation to the second policy and measures of promoting sustainable and deforestation-free agriculture. Thus, a key finding in this research is the importance of defining this causal link between direct and underlying drivers, and the role it plays in designing policy solutions to drivers.

The strongest options appear to be those policies defining clear mechanisms to address underlying drivers such as loopholes in laws and illegal activity (e.g., Criminal Code of 2015, Law of Forestry of 2017 and the FLEGT VPA). Others contain broad statements of interest to address tenure and livelihood needs via Provincial People's Committees allocating forest land to local communities, households and individuals (Decision 886 of 2017, Directive 13 of 2017, and the 2017 NRAP) and access to payments for ecosystem services for ethnic minorities (Decision 889 of 2013). Interviews indicate that this has been challenging to follow through on.

The Planning Law holds potential as means to enable synchronization between national planning and regional planning, and introduced new requirements for integrated planning, which could address sectoral disconnects that existed under the previous law. It will be useful to see how improved integrated planning between sectors provides a means to address weak governance and high commodity prices (although both rubber and coffee prices are currently very low).

The only policy that draws distinctive connections between the direct and underlying drivers is Directive 13. This Directive is a call to the Communist Party to strengthen leadership in retaining natural forest, and control the socioeconomic development which negatively affects forest area and quality, especially natural forests and protection forests. The cross-cutting underlying driver of high poverty rates in the forest dwelling communities, lack of access to land and forests, and poor tenure rights are targeted in the direction needed to complete the allocation of land and forests, providing land use rights to organizations, individuals, households and communities. Thus, Directive 13 is targeted at key actors (Communist Party Officials) at all levels. Yet, the Directive does not go as far as defining which direct drivers are prioritized for intervention.

In some geographic areas, the strongest underlying drivers that put pressures on farm soils and forests relate to poverty and finance [37], which have not been strongly reflected in rubber and coffee sector policy-making. The finance mechanisms and gaps in smallholder access to finance demonstrate a few relevant aspects for affecting drivers: (a) the banks' restrictions on lending due to the need to conform to Notice 191 has been effective, as it drew in actors (banks) that have a key role in financing sectors that have natively impacted forests; (b) the gaps that exist relative to poor and marginalized farmers accessing finance, who are the most at-risk to further deforest, are not reached through these finance mechanisms. Further, the finance mechanisms that they do access reinforce the underlying driver pressures. Besides district authorities arresting the poor for illegal logging, policy tools and mechanisms have yet to find a way to stop poor households from selling their farming lands and clearing new unregistered areas for cassava or coffee production.

\subsection{Policies Lacking Provisions Related to Drivers}

The 2012 NRAP omitted interventions aimed at the large drivers outside the forest sector and contained no mandate to agencies to evaluate and reconcile complex trade-offs between sectors, or a clear means to address underlying drivers. Fortunately, this was rectified with the 2017 NRAP, however many Provincial REDD+ Action Plans (PRAPs) were already completed by this time, especially in priority REDD+ areas. In the Central Highlands and other areas, these PRAPs were developed based 
on the 2012 NRAP and 2015 Guidelines for developing PRAPs issued by MARD [52]. Thus, the PRAPs lacked a focus on major agricultural driver commodities and related underlying drivers.

As the Forest Law could not contain provisions restricting agricultural expansion, agriculture sector laws would have been a more appropriate place to set such intentions. Yet, the Law on Crop Production, passed in 2018, does not contain mention of deforestation-free agricultural production, though it does contain language in Chapter 6 on adaptation to climate change and directs Provincial People's Committees to assess the impacts of climate change and help to guide solutions [53]. While this emphasis on climate adaptation is positive, the scope would not be broad enough to capture REDD+ mitigation goals.

The Five-Year Socio-Economic Development Plan (2016-2020) sought increases in rubber and coffee production, yet also prioritizes forest protection and production, and does not identify how this is to be reconciled in the Central Highlands. The orientation of the SEDP in the Central Highlands is towards large-scale commodity agriculture, to rapidly develop export-oriented industrial plants (coffee, rubber, tea, cotton, etc.) with the means of intensive cultivation, while also planting and protecting forests. However, the scale of demand-side pressures on rubber and coffee commodity production remains high, despite low commodity prices, with roughly USD 1 billion in rubber exports, mostly to China [54], and coffee exports averaging US\$ 3.0-3.5 billion annually, though this is falling, prompting farmers to switch to more valuable crops [55].

The Criminal Code (2015), Planning Law (2018), and the FLEGT VPA do not contain provisions specifically targeted at rubber and coffee drivers of land conversion, though they all notably contain interventions that address underlying drivers. The Criminal Code introduced criminal liability for companies and individuals in relation to forest management and the unlawful repurposing of land, and the penalties for all environmental crimes have increased.

\subsection{Policies with Objectives in Conflict with REDD+}

One year after the 2017 NRAP was approved, the government approved incentive policies for enterprises investing in agriculture and rural areas (Decree No. 57 of 2018) which provided preferential land prices for enterprises set by provincial/municipal People's Committees, rent exemptions and credit access and support [56]. This provided a major source of financial support to driver sectors and activities, yet there were no sustainability or deforestation-free conditions defined as a pre-requisite for accessing finance, nor reference to Notice No. 191 of 2016.

\subsection{Actors}

Most policies listed in Table 3 identify roles for government actors, from national to provincial and district levels. The 2017 NRAP comprehensively details the responsibilities of actors. What is most notable in all the policies reviewed is the relative absence of clearly defined interventions aimed at demand-side actors, particularly those buyers and markets that are making sustainability commitments. This would have been possible with a broader framing of the underlying drivers and the actors associated those. For instance, the Chinese Chamber of Commerce of Metals, Minerals and Chemicals Importers and Exporters (CCCMC) adopted new voluntary guidelines in 2017 for natural rubber, which contains a deforestation-free principle and guidance related to upholding national laws and land use planning, and local customary laws and practices, free-prior informed consent (FPIC) and other sensitivities around land tenure [57]. They are voluntary, and it is not yet clear how these are affecting Chinese company operations, or their suppliers. Interviews suggest that the Vietnamese government and rubber sector have not identified ways to mainstream these provisions in Vietnamese policy to assist Chinese buyers in attaining compliance, and there is a lack of awareness of the CCCMC guidelines at the production level.

Further, though international tire manufacturers such as Michelin, Pirelli, Goodyear, Bridgestone and others have made zero deforestation commitments [58-60], it is still unclear how much of Viet Nam's export market seeks these standards, as these companies do not appear to have clear sourcing 
links to Viet Nam, although some do source from China. However, pursuing these actors via the European Union-Viet Nam Free Trade Agreement (EVFTA), signed in 2018, which includes rubber and coffee, and thus key buyers could be brought to the table to forge solutions and leverage public and private action and investments in a coordinated fashion. Without a broader framing of the underlying drivers, opportunities to engage these actors and codify the marketplace deforestation-free commitments into national policy may not be as visible.

The largest group of actors involved in the rubber supply chain-smallholder producers-have not directly been targeted by policy interventions to date. While smallholders account for $88 \%$ of rubber production, smallholders capture the least benefit of all actors, accounting for only $10 \%$ of total profits [61]. Smallholders are often prone to price squeezing by traders, and with loose supply chain linkages and a lack of co-operation between actors [61], the quality of production and the stability of livelihoods of farmers is negatively impacted. Policy interventions that seek to stabilize smallholder expansion into forests which address the underlying drivers pushing their behaviour could include investments to raise production quality, thus contributing livelihood co-benefits, while seeking to reduce their expansion.

Similarly, in the coffee sector, marginalized and often ethnic minority farmers, lacking a clear title to land, are pushed by underlying driver pressures to expand, yet, as they are acting in response to these pressures, stopping their expansive activities pushes elsewhere and/or misses the key driver. Cassava provides the clearest example of this, as expansion into forests is largely undetectable, yet results in large-scale deforestation and soil degradation over time, making way for perennial commodity crops. As a USD 1 billion export commodity, its scale is not to be underestimated. However, it is largely unregulated, and these actors cannot be reached through existing finance mechanisms, and are often the most poor and marginalized, lacking clear land title. In both commodity contexts, defining positive incentives and interventions clearly directed at smallholder farmers, who bear the greatest burden for production pressures, price squeezing, commodity price fluctuations, and climate risk, have remained elusive.

Policy design and formulation processes to date have not included the large international roasters and traders buying coffee in the Central Highlands (including major international brands such as Nestlé, Lavazza, and Starbucks), with a view towards seeing transforming some actors' deforestation-free commitments into solutions on the ground.

Notably, the effect of implementing the natural forest moratorium (Notice 191) did bring in key actors, such as district and provincial level government, and banks, and their activities to advance compliance did affect underlying drivers (e.g., improved governance and reducing bank lending to farmers that cleared forest). This was not necessarily by design, but reflects commitment by the domestic banks to demonstrate compliance with Vietnamese law.

\subsection{Scales}

The policies reviewed here are all national-level commitments, and therefore not attuned to the regional differences in driver patterns, which are quite varied in Viet Nam. The Provincial-level REDD+ Action Plans that were developed in the Central Highlands were based on the 2012 NRAP, so similarly contained a focus on the forest sector, and largely omitted other drivers and underlying pressures. Viet Nam is currently planning activities to implement the 2017 NRAP, including seeking international financial support for integrated sustainable landscape management through a deforestation-free jurisdictional project in Lam Dong and Dak Nong Provinces.

As mentioned in the above section on actors, the international buyers and segments of commodity supply chains have not been drawn in. One limitation to the commitment by these large international companies to invest in the productivity of smallholder producers is the structure of the supply chain itself. Circular 08/2013/TT-BCT issued by the Ministry of Industry and Trade, mandates that foreign-owned companies are not permitted to source directly from farmers but must instead buy through a registered local company (or cooperative). This has resulted in significant challenges 
tracing coffee beans to the farm level, and in the overall traceability in the coffee sector. It has also impeded efforts by international roasters and buyers to reach smallholder producers with investments or technical support for improved production practices. Local collectors or aggregators are the links between smallholders and international buyers/traders. Collectors and traders are largely unregistered, operate on narrow price margins, and are under pressure from high competition [40].

\subsection{Future Driver Pressures}

Policy responses were designed in response to historical driver patterns. However, between the periods 2012 and 2017 NRAP, changes were already evident in the scope and scale of rubber and coffee drivers in the Central Highlands, mostly due to commodity prices. While important to chart the historical trajectory of drivers and underlying causes, the contemporary and future patterns are different, complex and interconnected. Coffee and rubber appear to be decreasing as a driver (source: district level interviews), while cassava and other crops are increasing [45].

An underlying driver that was not identified as a historical driver, but has increasingly been identified as problematic since the 2017 NRAP, is future climate change impacts. The Central Highlands are drier than other regions, thus risks to agriculture due to climate change are notable [62]. Unsustainable farming practices risk future production, particularly in the winter months when rainfall is expected to decrease [62], contributing to the over-exploitation of surface and ground water, with possible economic consequences, if not well managed. Droughts and floods had damaged key coffee growing regions in the Central Highlands in 2019 [63]. Climate modelling suggests that by 2050, climate change could regularly delay the rains until June, which would require much more water use than current levels [64]. The current reservoir capacity would likely not meet this need. Changing weather patterns will also shift the areas that are suitable for coffee production. Climate modelling also suggests that Robusta production will expand into higher altitudes, where many remaining forests are, and the demand for area exceeds the supply [65]. This indicates that future adaptation aspects should be considered in assessing drivers.

\subsection{Implications of Findings to the Global Context}

While there is great interest in finding forest and land use sector solutions to climate change under the Paris Agreement [66,67], the nuances of how to achieve such solutions through policy requires troubleshooting at national levels. This paper provides a national-level example demonstrating the importance of defining the linkages between direct and underlying drivers at the national-level, and the implications for attuning policy responses. This is highly relevant for countries seeking forest and land use sector solutions in NDCs as part of Paris Agreement climate commitments.

Brazil's response to direct and underlying drivers in the early 2000s provides ex-post evidence of the value of drawing linkages between the two, and attuning policy responses accordingly. The steps taken in the 2000s to reverse perverse incentives that drove Amazon clearing had an effect on addressing the underlying and direct drivers, while agricultural production increased [68]. Brazil held legal entities criminally liable for crimes against the environment [69], and linked the ability to access rural credit to a demonstration of legal compliance. In 2006, a voluntary ban on the commercialization of soy grown in the Amazon was set by private market players (since renewed), and the Bank of Brazil vetoed agricultural credit for soy farmers seeking to plant in newly cleared forest areas. This resulted in USD 1.4 billion not being loaned between 2008 through 2011 due to restrictions imposed by the resolution, and likely resulted in a 15 percent decrease in deforestation in the Amazon during the period [70].

Indonesia has also pursued deforestation moratoria, making permanent the moratoria on new concessions in primary forests and peatlands for palm oil and timber plantations, which was first enacted in 2011 [71]. However, Indonesia did not pursue a coordinated approach addressing the underlying drivers that were identified in its REDD+ National Strategy of 2012, particularly in reviewing the incentives and disincentives for the private sector and regions. Fiscal policies and perverse incentives were identified as key underlying drivers of oil palm expansion in Indonesia, but these have not yet 
been addressed through policy reform [72]. Indonesia took strides to address illegality in the forest sector (and related conversion timber) by implementing a timber legality verification system affecting domestic and export markets. Improved forest governance and law enforcement was found to have made it harder for producers to expand production by clearing forests [73]. However, Indonesia has recently removed these requirements, raising concerns that gains from improved timber legality verification may be lost [74]. Private sector 'deforestation-free' sourcing commitments and voluntary certification commitments are notable and long-standing, and one study found that areas certified under the Roundtable for Sustainable Palm Oil (RSPO) reduced deforestation by 33\% compared to areas not certified [75]. These private sector commitments have engaged key actors in the palm oil supply chain, from local to global scales.

The Indonesian and Brazilian contexts provide insight into how identification of the linkages between direct and underlying drivers influences assessment of policy responses. Mapping the conceptual linkages between direct and underlying drivers provides a means to explore the causal connections and reinforce the feedback loops that drive actors and behaviour. One of the most notable underlying drivers is increasing commodity prices driving plantation expansion, as evidenced in Indonesia (oil palm) [73], Cambodia (rubber) [76], and the pressure of rubber and coffee expansion in Viet Nam. While it is notably challenging for national governments to define policy responses to these underlying drivers, reaching the key actors at the scales they operate at, Brazil's commitments in the early 2000s offer the most robust success story in this regard. This research explores the conceptual basis that can illuminate the context-specific underlying drivers which are dynamic, complex, with nonlinear and historically specific characteristics. Although these country examples show what has been achieved (or not) to address the linkages between direct and underlying drivers through policy responses, the rate of agricultural commodity-driven deforestation has not decreased, and the conversion of forest to other land uses continues at 10 million ha per year (though this rate of loss is lower than in the 1990s [13,14].

\section{Conclusions}

In reviewing Viet Nam's policy responses to driver pressure, correlations between the direct drivers and related underlying drivers are unclear. This can be partly attributed to the fragmented and conflicting policy landscape that the NRAP needed to be integrated into. The 2017 NRAP had to integrate into a pre-existing policy landscape, and yet, even with fairly aligned policy vehicles such as the 2017 Forestry Law and Planning Law, the integration of REDD+ goals and mutual integration into these laws is not coherent. While this research did not elucidate insights as to why these disconnects occurred, it does draw out insights relevant to the importance of considering both the direct and underlying drivers (as per Figure 1), and how the policy formulation process does or does not bring that focus forward into defining interventions, which actors to target, and which scales to reach.

By considering the relationship between direct and underlying drivers, other options for addressing commodity pressure could have been more visible, such as considering export taxes on natural rubber, which would dampen international demand and provide the government with revenue to improve smallholder yields and practices. Another option would have been to investigate how marketplace deforestation-free commitments could be codified in national law (demonstrating to international buyers making such commitments that sourcing from Viet Nam would fulfill their pledge), or bringing these international buyers to the table to forge solutions, and leverage public and private action and investments in a more coordinated fashion.

There is debate about how effective policy can be in the face of strong commodity prices. Policy interventions on drivers often must be integrated into existing policy contexts, which is structurally challenging when the impetus often comes from a forest department, seeking to change an agriculture or industry mandate with large revenue and foreign-exchange implications. In Viet Nam, area-based commodity targets were far exceeded when commodity prices were high, and local regulation and enforcement could not reign in expansion into forests. The focus on commodity areas limited the scope 
of problem identification and the consideration of key actors and scales for engagement in the policy design process. This also raises questions about what could have been done differently (as the Brazil example in Section 4.8 illustrates), and whether existing policy tools hold the answers.

These research findings suggest that the elements in Figure 1 could be useful in designing policy responses to drivers, and are relevant to countries pursuing forest and land use sector solutions under the Paris Agreement. Each context is unique, and the arrangement of direct and underlying drivers, commodity supply chains, land tenure, and other factors will differ. However, applying Figure 1 as a framework to guide policy design and decision-making can identify the causal connections between direct and underlying drivers, including which future ones are expected. REDD+ in Viet Nam illustrates how important the adequate identification of all relevant drivers (including outside the forest sector) was to the robust development of the 2017 NRAP; it is also relevant to note how quickly pressures from other crops like cassava have outpaced more established crops such as coffee. Brazil completed a wide underlying driver assessment scoping the late 1990s and early 2000s, and the robust and interlinked policy responses which Brazil pursued as a result illustrates the benefits that can be achieved. Assessment of these aspects provides a basis for consideration of the types of incentives, disincentives and enabling measures capable of reaching the actors responsible for addressing the drivers, and what scale these may operate at (e.g. international, national and local). A view towards future driver pressures and exogenous pressures such as climate change provide a wider scope for considering interventions and possible implementation pathways. Economic and social ramifications are important to consider, particularly in relation to marginalized and tenure-insecure populations. Some of the strongest underlying drivers that put pressures on farms and forests in the Central Highlands relate to poor tenure rights, poverty and finance, and these have largely eluded the focus of policy interventions.

Funding: This research received no external funding.

Acknowledgments: The author wishes to thank Maria Brockhaus (International Forest Policy, University of Helsinki) for reviewing earlier versions of this manuscript. The author gratefully acknowledges the opportunity to utilize data collected while working for the UN-REDD Programme and UNDP Viet Nam Country Office in 2018 to develop a framework plan for deforestation-free jurisdictions in the Central Highlands—supporting the National REDD+ Action Programme's implementation in Viet Nam, which contributed to the development of this research. The author deeply appreciates all insights from interviewees in Hanoi, Ho Chi Minh City, Da Lat in Lam Dong Province, Gia Nghia in Dak Nong Province, and two districts in each of the provinces.

Conflicts of Interest: The author declares no conflict of interest. 


\section{Appendix A. Policies and Laws Related to NRAP Implementation- Long Version}

\begin{tabular}{|c|c|c|}
\hline Policy & Interventions Directed at Direct Drivers & Interventions Directed at Underlying Drivers \\
\hline General and forest sector & & \\
\hline $\begin{array}{l}\text { Law on Forestry-No. 16/2017/QH14 (November } \\
\text { 2017, came into force January 2019) }\end{array}$ & $\begin{array}{l}\text { Management direction for reserve, protection, and } \\
\text { production forests; } \\
\text { Defines power and roles for repurposing forests (to } \\
\text { other uses). }\end{array}$ & $\begin{array}{l}\text { - Centralizes decision making in natural forest conversion, seeking to } \\
\text { close loopholes }\end{array}$ \\
\hline $\begin{array}{l}\text { Voluntary Partnership Agreement between Viet } \\
\text { Nam and European Union (Signed 2018, came } \\
\text { into force June 2019) }\end{array}$ & $\begin{array}{l}\text { Defines mechanisms and processes to tackle illegal } \\
\text { logging and trade and improve forest governance; } \\
\text { Requires follow-on regulations needed to implement the } \\
\text { timber legality assurance system. }\end{array}$ & - Intended to address weaknesses in forest governance \\
\hline
\end{tabular}

- Article 6: Enterprises with agricultural projects eligible for investment incentives on leased land are entitled to preferential land

Incentive policies for enterprises investing in

agriculture and rural areas-Decree No. prices set by provincial/municipal People's Committees. Regulations 57/2018/ND-CP dated April 17th, 2018 and land rent to be stabilized for 5 years, rent exemptions for first 11-15 years;

- $\quad$ Article 8: Credit access and support.

Planning Law—Law No. 21/2017/QH14 (Effective

January 1, 2019)
- Seeks to enable synchronization between national planning and regional planning, and reform administrative procedures;

- Sets requirements for integrated planning.

- Seeks to overcome sectoral disconnects, though too early to evaluate whether implementation is achieving this objective.

- Article 2 introduces criminal liability for legal entities and persons;

- Article 229: Offences against regulations on land management (unlawful repurposing of land, including forest land);

Criminal code—Law No. 100/2015/QH13 (June

2017, came into effect January 1, 2018)
- Article 233. Offences against regulations on forest management;

- Article 243: Forest destruction allows for commercial legal entities to be subject to prosecution;Penalties for all environmental crimes increased. 


\section{Polic}

Decision No. 886/QD-TTg, (approved in June 2107) - Target Program for Sustainable Forest Development for the 2016-2020 Period

Decision No. 419/QD-TTg of Prime Minister (5 April 2017)—on the Reduction of Green-house Gas Emissions through the reduction of

Deforestation and Forest Degradation, Sustainable Management of Forest Resources, and

Conservation and Enhancement of Forest Carbon Stocks (2017 National REDD+ Action Programme)

Directive 13-CT/TW dated January 12, 2017 Enhancing Party's leadership in forest management, protection and development

The Five-Year Socio-Economic Development Plan (2016-2020) —Resolution No. Resolution No. 142/2016/QH13

Prime Minister's Notice No. 191/TB-VPCP dated 22/7/2016 - Conclusion of the Prime Minister at the Conference on Sustainable

Forest Restoration Solutions in the Central Highlands (2016-2020).
- National forest cover goal of $42 \%$, and forest area of 14.4 million ha;

- $15 \%$ of degraded forest ecosystem area is restored and preserved.
- Requests Provincial People's Committees speed up forest allocation and lease to organizations, local communities, households and individuals.

- Review and adjust the land use master plan- target of 16.24 million hectares of forest land by 2020 , increase forest cover to $45 \%$ of national territory;

- Promote sustainable and deforestation-free agriculture and aquaculture.

- Direction to Communist Party to strengthen leadership in forest management, protection and development with the major focus on retaining natural forest;

Complete allocation of land and forests, and the certification of forest land

- Request to control socioeconomic development planning and projects negatively affecting forest's area and quality, especially natural forest and protection forest.
- Improve forest governance and livelihoods, strengthen law enforcement;

- Coordination and accountability of related ministries with leader's roles clarified.
- Forest coverage by 2020 will be $42 \%$;

- $\quad$ For Central Highlands, large-scale commodity agriculture, rapidly develop export-oriented industrial plants (coffee, rubber, tea, cotton, etc.) with the means of intensive cultivation, breeding large cattle, planting and protecting forests (p. 90).

- $\quad$ Affirms and builds on Conclusion No. 97-KL/TW dated 9/5/2014 of the Political Bureau on natural forest logging ban or 'closing natural forest.'

- Conserve existing natural forests of 2.25 Mha and no conversion allowed;

- No conversion of poor natural forests to industrial crops such as rubber or coffee. 
- Does not mention deforestation-free agriculture or REDD+ goals.

Viet Nam's Nationally Determined Contribution to Paris Climate Agreement (NDC), submitted to UNFCCC in October 2015

Prime Minister's Decision No. 799/QD-TTg dated

27 June 2012 on Approval of the National Program on Reduction of Greenhouse Gas Emissions through Efforts to Reduce Deforestation and Forest Degradation, Sustainable Management of Forest Resources, and Conservation and

Enhancement of Forest Carbon Stocks, 2011-2020 (2012 National REDD+ Action Programme)

Decree 99 of 2010 on Policy on Payment for Forest Environmental Services (PFES)

\section{Sector-specific: Rubber}

Directive No. 1685 / CT-TTg o

2011-Strengthening forest protection, preventing forest destruction, and countering attacks of fores protection staff

Decision of the Prime Minister 899/QD-TTg, 2013 -Agricultural restructuring towards raising added values and sustainable development
- Increase forest cover to $45 \%$ by 2030 (from under $40 \%$ in 2010);

- Requires further domestic policy for implementation.

- An evaluation at end of the 1 st phase of it implementation (2011-2015) determined the NRAP direction should be revised for Phase II, and scope of driver assessment to be broadened.
- Directs revenue from environmental service users to environmental service providers such as forest owners and households, to incentivize their role to maintain forest cover. Lacks a results-based performance measure for receiving funds.
- $\quad$ Resulted in mandate from Provincial People's Committee to review and evaluate projects converting forest to rubber plantations, and district Departments of Agriculture and Rural Development to adjust rubber plantation development plans.
- $\quad$ Lam Dong DARD review in response to this Directive reduced planned rubber area;

- Lam Dong DARD also identified significant areas planted fall far short of the goals identified in the original investment certificates, which provides a basis to propose they revert back to forest.
- Increase rubber tree area to 800,000 hectares in the South East and Central Highlands (Tay Nguyen).
- Promote economic value from forests, while maintaining environmental services and access to PES for ethnic minorities. 
- Invests USD 98.7 million in the coffee sector between 2015 and 2020;

Viet Nam Sustainable Agriculture Transformation

- Improved farm agronomic and management practices (VNSat) programme on 69,000 ha with 62,500 coffee growers in 12 districts:

- Rejuvenate aging coffee trees and develop monitoring systems.

- Stabilize coffee area at 600,000 hectares, with $80 \%$ of area under improved management practices (via certification standards such as UTZ, 4C Rainforest Alliance, and VietGAP).

Decision of the Prime Minister 899/QD-TTg, 2013-Agricultural restructuring towards raising added values and sustainable development
- Stabilize the coffee area at 500,000 hectares (primarily in Central Highlands, but includes others as well).
- Promote economic value from forests, while maintaining environmental services and access to PES for ethnic minorities. 


\section{References}

1. FAO. Global Forest Resources Assessment 2015: Vietnam Country Report. Available online: http://www.fao. org/3/a-az373e.pdf (accessed on 24 June 2020).

2. MARD. Modified Submission of Reference Level for REDD+ Results Based Implementation in Vietnam. Available online: http://redd.unfccc.int/files/vietnam_frl_modified_submission_final_for_posting.pdf (accessed on 5 June 2018).

3. McNally, R.; Phuong, V.T.; Nguyen, T.C.; Pham, X.P.; Nguyen, V.D. Issues and Options: Support for the Revision of the Viet Nam's National REDD+ Action Programme (NRAP) 2016-2020; UNDP Viet Nam: Hanoi, Vietnam, 2016.

4. Decision 1/CP. 16 The Cancun Agreements; UNFCCC: Cancun, Mexico, 2010; Available online: https: //unfccc.int/resource/docs/2010/cop16/eng/07a01.pdf\#page=12 (accessed on 3 July 2020).

5. Decision 9/CP. 19 The Warsaw Framework; UNFCCC: Warsaw, Poland, 2013; Available online: https: //unfccc.int/resource/docs/2013/cop19/eng/10a01.pdf\#page=24 (accessed on 3 July 2020).

6. Global Environmental Facility. GEF-7 Replenishment Programming Directions. GEF/R.7/19. In Proceedings of the Fourth Meeting for the Seventh Replenishment of the GEF Trust Fund, Global Environmental Facility, Stockholm, Sweden, 25 April 2018.

7. World Bank. 10 Years: Marking 10 Years of Action for Forests and Climate; World Bank: Washington, DC, USA, 2018.

8. UN-REDD Programme-10 Years UN-REDD Programme. 2018. Available online: https://www.10year.unredd.org/ (accessed on 6 December 2018).

9. Frechette, A.; de Bresser, M.; Hofstede, R. External Evaluation of the United Nations Collaborative Programme on Reducing Emissions from Deforestation and Forest Degradation in Developing Countries (the UN-REDD Programme); UN Environment Evaluation Office: Nairobi, Kenya, 2014; Volume I.

10. Korhonen-Kurki, K.; Brockhaus, M.; Sehring, J.; Di Gregorio, M.; Assembe-Mvondo, S.; Babon, A.; Bekele, M.; Benn, V.; Gebara, M.F.; Kambire, H.W.; et al. What drives policy change for REDD+? A qualitative comparative analysis of the interplay between institutional and policy arena factors. Clim. Policy 2018, 19, 315-328. [CrossRef]

11. Busch, J.; Ferretti-Gallon, K. What Drives Deforestation and What Stops It? A Meta-Analysis. Rev. Environ. Econ. Policy 2017, 11, 3-23. [CrossRef]

12. Lambin, E.; Meyfroidt, P.; Rueda, X.; Blackman, A.; Börner, J.; Cerutti, P.O.; Dietsch, T.; Jungmann, L.; Lamarque, P.; Lister, J.; et al. Effectiveness and synergies of policy instruments for land use governance in tropical regions. Glob. Environ. Chang. 2014, 28, 129-140. [CrossRef]

13. Curtis, P.; Slay, C.; Harris, N.; Tyukavina, A.; Hansen, M. Classifying drivers of global forest loss. Science 2018, 361, 1108-1111. [CrossRef]

14. The State of the World's Forests 2020: Forests, Biodiversity and People; FAO and UNEP: Rome, Italy, 2020. [CrossRef]

15. Geist, H.; Lambin, E. Proximate causes and underlying driving forces of tropical deforestation. BioScience 2002, 52, 143-150. [CrossRef]

16. Kissinger, G.; Herold, M.; de Sy, V. Drivers of Deforestation and Forest Degradation: A Synthesis Report for REDD+ Policymakers; Lexeme Consulting: Vancouver, BC, Canada, August 2012.

17. Vo, Q.; Le, T.C. Conservation of forest resources and the greater biodiversity of Vietnam. Asian J. Environ. Manag. 1994, 2, 55-59.

18. Meyfroidt, P.; Lambin, E. Forest transition in Vietnam and its environmental impacts. Glob. Chang. Biol. 2008, 14, 1319-1336. [CrossRef]

19. Meyfroidt, P.; Lambin, E. The causes of the reforestation in Vietnam. Land Use Policy 2008, 25, $182-197$. [CrossRef]

20. Cochard, R.; Ngo, D.T.; Waeber, P.O.; Kull, C.A. Extent and causes of forest cover changes in Vietnam's provinces 1993-2013: A review and analysis of official data. Environ. Rev. 2017, 25, 199-217. [CrossRef]

21. Khuc, Q.V.; Tran, B.Q.; Meyfroidt, P.; Paschke, M. Drivers of deforestation and forest degradation in Vietnam: An exploratory analysis at the national level. For. Policy Econ. 2018, 90, 128-141. [CrossRef]

22. IPSARD. Action Plan Integrating REDD+ into Rubber Development; UN-REDD: Hanoi, Vietnam, 2015. 
23. General Statistics Office of Vietnam. Statistics for Agriculture, Forestry and Fishing. 2017. Available online: https://www.gso.gov.vn/default_en.aspx?tabid=778 (accessed on 25 July 2018).

24. Pham, T.T.; Moeliono, M.; Nguyen, T.H.; Nguyen, H.T.; Vu, T.H. The Context of REDD+ in Vietnam: Drivers, Agents and Institutions; Occasional Paper 75; CIFOR: Bogor, Indonesia, 2012.

25. Marsh, A. Diversification by Smallholder Farmers: Viet Nam Robusta Coffee; Food and Agriculture Organization of the United Nations, Agricultural Management, Marketing and Finance Service: Rome, Italy, 2007.

26. Land use, forest cover change and historical GHG emission from 1990 to 2010: Lam Dong province, Viet Nam. In Lowering Emissions in Asia's Forests; USAID: Hanoi, Vietnam, 2013.

27. MARD. The Central Highlands Provinces Should Prevent the Development of Mass Cassava. 2017. Available online: https://www.mard.gov.vn/Pages/cac-tinh-tay-nguyen-can-ngan-chan-tinh-trang-phat-trien-caysan-o-at.aspx (accessed on 30 July 2018). (In Vietnamese)

28. General Statistics Office of Viet Nam. Statistical Data, Agriculture, Forestry and Fisheries. Available online: https://www.gso.gov.vn/ (accessed on 20 July 2018).

29. MARD. Decision No. 3158/BNN-TCLN; Ministry of Agriculture and Rural Development: Hanoi, Vietnam, 27 July 2016.

30. Report on the 10-Year Review of the 7th Central Committee Resolution X; Dak Nong DARD: Dak Nong, Vietnam, 2018.

31. Index Mundi. Commodity Prices: Rubber. 2019. Available online: https://www.indexmundi.com/ commodities/?commodity=rubber\&months=120 (accessed on 4 December 2019).

32. Decision, No. 750/QD-TTg of the Prime Minister on Rubber Development to 2015 and Vision to 2020; Government of Viet Nam: Hanoi, Vietnam, 2015.

33. Report: Approving the Results of Reviewing and Adjusting the Planning on Development of Rubber Plantation in Lam Dong Province; Submitted to Lam Dong People's Committee in response to Document No. 5102/UBND LN dated 29/8/2013; Lam Dong DARD: Lam Dong, Vietnam, 2013.

34. Phuc, X.; Nghi, T.H. Rubber Expansion and Forest Protection in Vietnam; Tropenbos International Viet Nam and Forest Trends: Hue, Vietnam, 2014.

35. Forest Stewardship Council. Forest Stewardship Council disassociates from the Viet Nam Rubber Group. 2015. Available online: https://ic.fsc.org/en/news-updates/fsc-press-releases/id/1288 (accessed on 23 September 2018).

36. Indochina Research and Consulting JSC (IRC). Research Analysis of Coffee Value Chain of Vietnam, Report to Sustainable Agriculture Conversion Project in Vietnam (VNSAT); Indochina Research and Consulting: Hanoi, Vietnam, 2018.

37. Thaái, H.A.C. Livelihood Pathways of Indigenous People in Vietnam's Central Highlands: Exploring Land-Use Change; Springer: Heidelberg, Germany, 2018.

38. Thi Mai Duong, N.; Khang, L.N.; Truong, L.C.; Van Kien, P.; Van Hao, N. Analyzing causes of deforestation and forest degradation as a basis for proposing forest management and protection solutions in Dak Nong province. J. For. Sci. Technol. No. 06/2016 2016, 39-48.

39. Dak Nong Provincial Committee of Ethnic Minorities. Situation and Resolution of Restricted Migrants After 10 Years of Establishment of Dak Nong Province. 2014. Available online: http: //bdt.daknong.gov.vn/content/th\%E1\%BB\%B1c-tr\%E1\%BA\%A1ng-v\%C3\%A0-gi\%E1\%BA\%A3i-ph\%C3\% A1p-h\%E1\%BA $\% A 1 n-c h \% E 1 \% B A \% B F-d \% C 3 \% A 2 n-d i-c \% C 6 \% B 0-t \% E 1 \% B B \% B 1-d o-s a u-g \% E 1 \% B A \%$ A7n-10-n\%C4\%83m-th\%C3\%A0nh-1\%E1\%BA\%ADp-t\%E1\%BB\%89nh-\%C4\%91\%C4\%83k-n\%C3\%B4ng (accessed on 21 May 2018).

40. Hurri, S.; Quang, N.N. Rural Finance of Coffee Smallholders in Vietnam-Case Study in Dak Nong Province; IFAD Field Report; International Fund for Agricultural Development: Hanoi, Vietnam, 2015.

41. Ha, D.T.; Shively, G. Coffee boom, coffee bust and smallholder response in Vietnam's central highlands. Rev. Dev. Econ. 2008, 12, 312-326. [CrossRef]

42. Doutriaux, S.; Geisler, C.; Shively, G. Competing for Coffee Space: Development-Induced Displacement in the Central Highlands of Vietnam. Rural Sociol. 2008, 73, 528-554. [CrossRef]

43. Meyfroidt, P.; Tan, P.V.; Viet, A.H. Trajectories of deforestation, coffee expansion and displacement of shifting cultivation in the Central Highlands of Vietnam. Glob. Environ. Chang. 2013, 23, 1187-1198. [CrossRef] 
44. Viet Nam Customs. Customs Trade Statistics. 2017. Available online: https://www.customs.gov.vn/ Lists/EnglishStatistics/Default.aspx?language=en-US\&Group=Customs\%20Trade\%20Statistics (accessed on 15 May 2018).

45. Vân, N.H.; Lãm, N.X.; và Hà Công Liêm, H.C. Cassava Up, Forest Down: Case Study in Viet Nam; PanNature: Hanoi, Vietnam, 2016. (In Vietnamese)

46. Vietnam—s coffee growers face profit squeeze from bumper crop. Financial Times, 21 August 2018.

47. USDA Foreign Agricultural Service. Vietnam Coffee Annual Report 2017; United States Department of Agriculture: Washington, DC, USA, 2017.

48. Decision, No. 419/QD-TTg (2017) on the Reduction of Green-House Gas Emissions through the Reduction of Deforestation and Forest Degradation, Sustainable Management of Forest Resources, and Conservation and Enhancement of Forest Carbon Stocks (2017 National REDD+ Action Programme); Government of Viet Nam: Hanoi, Vietnam, 2017.

49. Decision 886/QD-TTg. Decision on Approving the Target Programme for Sustainable Forest Development for the 2016-2020 Period; Government of Viet Nam: Hanoi, Vietnam, 2017.

50. Sustainable Coffee Plan to 2020 and Vision to 2030; Government of Viet Nam: Hanoi, Vietnam, 2016.

51. Project Appraisal Document: Vietnam Sustainable Agriculture Transformation Project; Report No: PAD1168; World Bank: Washington, DC, USA, 2015.

52. Decision, No. 5414/QD-BNN-TCLN Dated 25 December 2015 on Approval of the Guidelines on Development of Provincial Action Plans on Reducing Greenhouse Gas Emissions through Efforts to Reduce Deforestation and Forest Degradation, Sustainable Forest Management, and Conservation and Enhancement of Forest Carbon Stocks (REDD+); MARD: Hanoi, Vietnam, 2015.

53. Law on Crop Production; Government of Viet Nam: Hanoi, Vietnam, 2018.

54. UN Comtrade Database. 2018. Available online: https://comtrade.un.org/data (accessed on 5 July 2018).

55. Coffee price crisis hits Vietnamese export value. Viet Nam News. 16 December 2019. Available online: https://vietnamnews.vn/economy/569894/coffee-price-crisis-hits-vietnamese-export-value.html (accessed on 14 June 2020).

56. Government of Viet Nam. Decree No.: 57/2018/ND-CP Dated April 17, 2018 of the Government on Incentive Policies for Enterprises Investing in Agriculture and Rural Development Sector; Ministry of Planning and Investment: Hanoi, Vietnam, 2018.

57. China Chamber of Commerce of Metals, Minerals \& Chemicals Importers and Exporters. Guidance for Sustainable Natural Rubber. 2017. Available online: http://en.cccmc.org.cn/news/cccmcinformation/72549. htm (accessed on 1 June 2020).

58. Bridgestone Group. Global Sustainable Procurement Policy. 2018. Available online: https://www.bridgestone. com/responsibilities/procurement/pdf/Policy_English.pdf (accessed on 20 September 2019).

59. Pirelli. Pirelli Sustainable Natural Rubber Policy. 2017. Available online: https://s3.eu-west-1.amazonaws. com/psi-dotcom-prd/corporate/2164_English_Version.pdf (accessed on 28 June 2018).

60. Michelin Tire Company. Sustainable Natural Rubber Policy. 2016. Available online: https://michelinmedia. com/site/user/files/1/SUSTAINABLE-NATURAL-RUBBER-POLICY_VD.pdf (accessed on 28 June 2018).

61. Hanh, N.T.T. Solutions to improve the value added of the rubber value chain in the Central Highlands of Vietnam. Australas. Agribus. Perspect. 2018, 21, 89-97.

62. Government of Viet Nam. Climate Change and Sea Level Rise Scenarios for Viet Nam; Ministry of Natural Resources and Environment: Hanoi, Vietnam, 2016.

63. Viet Nam Net Global, Coffee Price Crisis Hits Vietnamese Export Value. 16 December 2019. Available online: https://vietnamnet.vn/en/business/coffee-price-crisis-hits-vietnamese-export-value-599456.html (accessed on 15 May 2020).

64. Grosjean, G.; Monteils, F.; Hamilton, S.D.; Blaustein-Rejto, D.; Gatto, M.; Talsma, T.; Bourgoin, C.; Sebastian, L.S.; Catacutan, D.; Mulia, R.; et al. Increasing Resilience to Droughts in Vietnam: The Role of Forests, Agroforests and Climate Smart Agriculture; CCAFS-CIAT-UN-REDD: Hanoi, Vietnam, 2016.

65. Killeen, T.; Harper, G. Coffee in the Twenty First Century: Will Climate Change and Increased Demand Lead to New Deforestation? Conservation International: New York, NY, USA, 2016.

66. Griscom, B.W.; Busch, J.; Cook-Patton, S.C.; Ellis, P.W.; Funk, J.; Leavitt, S.M.; Lomax, G.; Turner, W.R.; Chapman, M.; Engelmann, J.; et al. National mitigation potential from natural climate solutions in the tropics. Philos. Trans. R. Soc. B 2020, 375, 20190126. [CrossRef] 
67. Kissinger, G.; Gupta, A.; Mulder, I.; Unterstell, N. Climate financing needs in the land sector under the Paris Agreement: An assessment of developing country perspectives. Land Use Policy 2019, 83, 256-269. [CrossRef]

68. Macedo, M.; DeFries, R.; Morton, D.; Stickler, C.; Galford, G.; Shimabukuro, Y. Decoupling of deforestation and soy production in the southern Amazon during the late 2000s. Proc. Natl. Acad. Sci. USA 2012, 109, 1341-1346. [CrossRef]

69. Government of Brazil. Environmental Crimes Act; Law 9605 of 1998. 1998. Available online: www.planalto. gov.br/ccivil_03/leis/19605.htm (accessed on 30 June 2020).

70. Assunção, J.; Gandour, C.; Rocha, R.; Rocha, R. Does Credit Affect Deforestation? Evidence from a Rural Credit Policy in the Brazilian Amazon; Climate Policy Initiative: Rio de Janeiro, Brazil, 2013.

71. Reuters. Indonesia President Makes Moratorium on Forest Clearance Permanent. 2019. Available online: https://www.reuters.com/article/us-indonesia-environment-forest-idUSKCN1UY14P (accessed on 8 August 2019).

72. United Nations Environment Program. Fiscal Incentives for Indonesian Palm Oil Production: Pathways for Alignment with Green Growth; United Nations Environment Program: Nairobi, Kenya, 2016.

73. Gaveau, D.; Locatelli, B.; Salim, M.A.; Yaen, H.; Pacheco, P.; Sheil, D. Rise and fall of forest loss and industrial plantations in Borneo (2000-2017). Conserv. Lett. 2019, 12, e12622. [CrossRef]

74. Maryudi, A.; Kartodihardjo, H.; Putro, H. A Review of Ministry of Trade Regulation No. 15/2020: Safeguarding Indonesia's Forest Product Exports; Policy Brief of Faculty of Forestry, University of Gadjah Mada: Yogyakarta, Indonesia, 2020. Available online: http://sebijak.fkt.ugm.ac.id/wp-content/uploads/sites/959/2020/04/PolicyBrief-Safeguarding-Indonesia\%E2\%80\%99s-Forest-Product-Exports-English.pdf (accessed on 30 June 2020).

75. Carlson, K.M.; Heilmayr, R.; Gibbs, H.K.; Noojipady, P.; Burns, D.N.; Morton, D.C.; Walker, N.F.; Paoli, G.D.; Kremen, C. Effect of oil palm sustainability certification on deforestation and fire in Indonesia. Proc. Natl. Acad. Sci. USA 2018, 115, 121-126. [CrossRef]

76. Grogan, K.; Pflugmacher, D.; Hostert, P.; Mertz, O.; Fensholt, R. Unravelling the link between global rubber price and tropical deforestation in Cambodia. Nat. Plants 2019, 5, 47-53. [CrossRef] [PubMed]

(C) 2020 by the author. Licensee MDPI, Basel, Switzerland. This article is an open access article distributed under the terms and conditions of the Creative Commons Attribution (CC BY) license (http://creativecommons.org/licenses/by/4.0/). 